\title{
COMMENTARY
}

\section{Dopexamine: immunomodulatory, hemodynamic, or both?}

\author{
Steven M Hollenberg* \\ See related research by Bangash et al., http://ccforum.com/content/17/2/R57
}

\begin{abstract}
Dopexamine is a dopamine analog that has been used for hemodynamic optimization in a number of clinical settings. This animal investigation showed antiinflammatory effects of dopexamine in a rat endotoxin model without effects on global or regional flow, but it is not time to dispense with hemodynamics altogether just yet. Rather, an integrative approach to the effects of catecholamines, considering both inflammatory and hemodynamic effects, including those on the microcirculation, can help clinicians best understand how to employ them in clinical practice.
\end{abstract}

\section{Introduction}

Busy clinicians sometimes think twice before reading studies of animal models. Yes, it sounds interesting, but is it really going to change my practice? There is so much else I should be reading... This writer does not mean to cast aspersions on such an attitude - and, in fact, shares it, at least to some extent. Animal studies are most useful when they illuminate clinical issues. The report in the previous issue of Critical Care by Bangash and colleagues is one such study [1].

Dopexamine is a dopamine analog that stimulates $\beta$ adrenergic and dopamine 1 and 2 receptors, conferring some vasodilatory effects. Dopexamine has classically been considered a vasoactive agent with inotropic effects, perhaps with more prominent effects in some regional vascular beds. As such, dopexamine has been tested in clinical trials to optimize hemodynamics, either in patients with shock or as part of a perioperative regimen.

\section{Inotropic therapy to optimize hemodynamics}

The clinical benefits of inotropic therapy for hemodynamic optimization remain somewhat uncertain. Myocardial

*Correspondence: Hollenberg-steven@cooperhealth.edu

Divisions of Critical Care Medicine and Cardiology, Cooper University Hospital, One Cooper Plaza, 366 Dorrance, Camden, NJ 08103, USA dysfunction occurs in a subset of patients with septic shock [2], so a strategy of increasing cardiac output and thus oxygen delivery in this setting made some sense. Implementation of this strategy using dobutamine, with or without norepinephrine, to improve cardiac output to predetermined supranormal levels in all patients did not improve outcomes [3-5], and use of inotropic therapy for this purpose is not recommended in current guidelines [5]. Subsequent reports of potentially deleterious proinflammatory effects of catecholamines provided mechanistic support for their lack of efficacy when used indiscriminately [6].

\section{Dopexamine may be different}

Use of dopexamine targeted to increase oxygen delivery to $>600 \mathrm{ml} / \mathrm{minute} / \mathrm{m}^{2}$, however, was shown in a randomized trial reported in 1993 to decrease mortality in the perioperative period [7]. Whether this resulted from differential hemodynamic effects of dopexamine compared with other agents, perhaps selective vasodilation of regional circulations, or whether use of inotropes for perioperative optimization is different from their use in other settings was not entirely settled.

\section{Or is it?}

Further studies since that time have advanced the field without providing complete resolution. Some reports using perioperative dopexamine found reduced morbidity or mortality $[8,9]$, confirming the initial study, but others found no difference from conventional treatment [10-12]. A patient-level meta-analysis suggested that some of the differences might be explained by the dose of dopexamine employed [13]. Other studies indicated that dopexamine - in part due to $\beta_{2}$-adrenergic effects, but also through other pathways - might have immunomodulatory effects, especially in the spleen [14].

\section{Inflammation or hemodynamics?}

The current study investigated both hemodynamic and inflammatory effects of a low dose of dobutamine in a rodent model of endotoxemia. Dopexamine reduced the systemic inflammatory response to endotoxin, including 
cytokine release, endothelial adhesion molecules, and oxidative stress, without substantially changing systemic hemodynamics, either blood pressure or stroke volume [1]. Regional flow, assessed by laser Doppler in the mesenteric circulation, was also not changed by dopexamine yet lactate levels and organ function were improved [1]. The authors concluded that beneficial effects of dopexamine may result from immune modulation.

\section{Or both?}

While immunomodulatory effects of dopexamine were demonstrated in this study, these results contrast with those of a recent clinical investigation, also carried out by this same group, in which dopexamine improved global oxygen delivery, microvascular flow and tissue oxygenation but did not change the inflammatory response to surgery [15]. Perhaps the difference could result in part from microcirculatory heterogeneity, something not assessed by the laser Doppler methodology used in this study. Previous studies have shown that regional heterogeneity may be a good predictor of outcome in shock states $[16,17]$, and such heterogeneity might contribute to both perfusion abnormalities and production of lactate in sepsis and other inflammatory states. Thus, while this study convincingly demonstrates immunomodulatory effects of dopexamine in this model, it seems possible that microcirculatory hemodynamic effects are also playing a role.

\section{An integrative approach}

This animal study addresses some of the mystery of why effects of dopexamine may differ from those of other catecholamines, but that mystery is not yet fully solved. Hemodynamics rule, and those who understand them rock, but this study reminds us that catecholamines have inflammatory effects that must be taken into account when considering their use. Animal studies are usually pursued as part of a reductionist approach aimed at controlling as many variables as possible in order to isolate mechanistic effects, but their interpretation and extrapolation to the clinical setting reminds us that in critical care, clinicians think of effects on different systems all together. Carefully conducted studies such as this one counteract the nihilistic tendency to think that mechanisms are too complicated and thus only hard clinical endpoints in patients are of any value, and encourage the sort of integrative approach that makes progress possible.

\section{Competing interests}

The author declares that he has no competing interests.
References

1. Bangash MN, Patel NSA, Benetti E, Collino M, Hinds CJ, Thiemermann C, Pearse RM: Dopexamine can attenuate the inflammatory response and protect against organ injury in the absence of significant effects on hemodynamics or regional microvascular flow. Crit Care 2013, 17:R57.

2. Parker MM, Shelhamer JH, Bacharach SL, Green MV, Natanson C, Frederick TM, Damske BA, Parrillo JE: Profound but reversible myocardial depression in patients with septic shock. Ann Intern Med 1984, 100:483-490.

3. Gattinoni L, Brazzi L, Pelosi P, Latini R, Tognoni G, Pesenti A, Fumagalli R, Group SC: A trial of goal-oriented hemodynamic therapy in critically ill patients. NEngl J Med 1995, 333:1025-1032.

4. Hayes MA, Timmins AC, Yau EHS, Palazzo M, Hinds CJ, Watson D: Elevation of systemic oxygen delivery in the treatment of critically ill patients. NEngl J Med 1994, 330:1717-1722.

5. Hollenberg SM, Ahrens TS, Annane D, Astiz ME, Chalfin DB, Dasta JF, Heard SO, Martin C, Napolitano LM, Susla GM, Totaro R, Vincent JL, Zanotti-Cavazzoni S: Practice parameters for hemodynamic support of sepsis in adult patients: 2004 update. Crit Care Med 2004, 32:1928-1948.

6. Singer M: Catecholamine treatment for shock - equally good or bad? Lancet 2007, 370:636-637.

7. Boyd O, Grounds RM, Bennett ED: A randomized clinical trial of the effect of deliberate perioperative increase of oxygen delivery on mortality in high-risk surgical patients. J Am Med Assoc 1993, 270:2699-2707.

8. Wilson J, Woods I, Fawcett J, Whall R, Dibb W, Morris C, McManus E: Reducing the risk of major elective surgery: randomised controlled trial of preoperative optimisation of oxygen delivery. BMJ 1999, 318:1099-1103.

9. Pearse R, Dawson D, Fawcett J, Rhodes A, Grounds RM, Bennett ED: Early goal-directed therapy after major surgery reduces complications and duration of hospital stay. A randomised, controlled trial [ISRCTN38797445]. Crit Care 2005, 9:R687-R693.

10. Takala J, Meier-Hellmann A, Eddleston J, Hulstaert P, Sramek V: Effect of dopexamine on outcome after major abdominal surgery: a prospective, randomized, controlled multicenter study. European Multicenter Study Group on Dopexamine in Major Abdominal Surgery. Crit Care Med 2000, 28:3417-3423.

11. Stone MD, Wilson RJ, Cross J, Williams BT: Effect of adding dopexamine to intraoperative volume expansion in patients undergoing major elective abdominal surgery. Br J Anaesth 2003, 91:619-624.

12. Davies SJ, Yates D, Wilson RJ: Dopexamine has no additional benefit in high-risk patients receiving goal-directed fluid therapy undergoing major abdominal surgery. Anesth Analg 2011, 112:130-138.

13. Pearse RM, Belsey JD, Cole JN, Bennett ED: Effect of dopexamine infusion on mortality following major surgery: individual patient data metaregression analysis of published clinical trials. Crit Care Med 2008, 36:1323-1329.

14. Oberbeck R, Schmitz D, Schuler M, Wilsenack K, Schedlowski M, Exton M: Dopexamine and cellular immune functions during systemic inflammation. Immunobiology 2004, 208:429-438.

15. Jhanji S, Vivian-Smith A, Lucena-Amaro S, Watson D, Hinds CJ, Pearse RM: Haemodynamic optimisation improves tissue microvascular flow and oxygenation after major surgery: a randomised controlled trial. Crit Care 2010, 14:R151

16. Trzeciak S, Dellinger RP, Parrillo JE, Guglielmi M, Bajaj J, Abate NL, Arnold RC, Colilla S, Zanotti S, Hollenberg SM: Early microcirculatory perfusion derangements in patients with severe sepsis and septic shock: relationship to hemodynamics, oxygen transport, and survival. Ann Emerg Med 2007, 49:88-98, 98.e1-98.e2.

17. Edul VS, Enrico C, Laviolle B, Vazquez AR, Ince C, Dubin A: Quantitative assessment of the microcirculation in healthy volunteers and in patients with septic shock. Crit Care Med 2012, 40:1443-1448. 